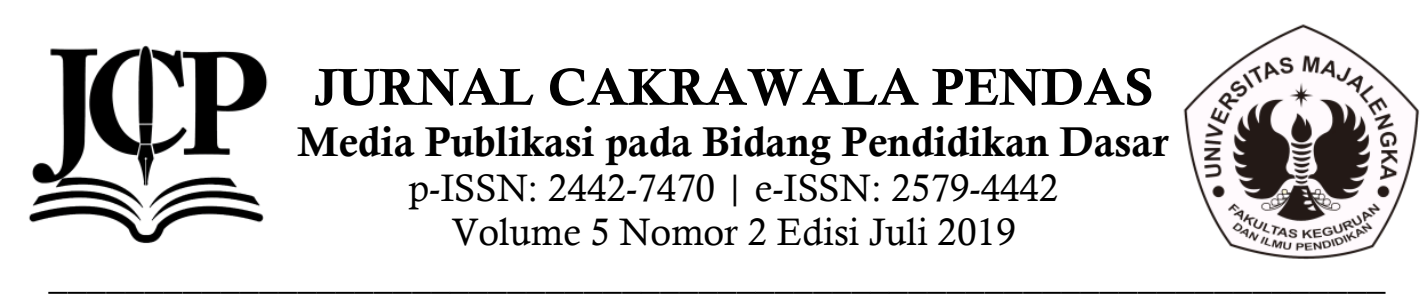

\title{
UPAYA MENINGKATKAN KEAKTIFAN DAN HASIL BELAJAR IPA MELALUI MODEL DISCOVERY LEARNING DI KELAS IV SD
}

\author{
Edy Sispariyanto ${ }^{1}$. Stefanus C Relmasira ${ }^{2}$, Agustina Tyas Asri Hardini ${ }^{3}$ \\ PGSD FKIP Universitas Kristen Satya Wacana \\ e-mail : 292013070@student.uksw.edu1..Stefanus.relmasira@staff.uksw.edu² \\ Tyas.asri@staff.uksw.edu ${ }^{3}$
}

\begin{abstract}
Abstrak
Penelitian ini dilatar belakangi oleh keaktifan dan hasil belajar siswa yang masih rendah di SD Negeri Karangtengah 01 pada muatan IPA. Tujuan penelitian untuk meningkatkan keaktifan dan hasil belajar IPA melalui penerapan pembelajaran Discovery Learning. Jenis penelitian menggunakan Penelitian Tindakan Kelas (PTK). Teknik pengumpulan data melalui observasi, tes dan studi dokumen. Subjek penelitian adalah siswa kelas IV SD Karangtengah 01 yang berjumlah 22. Alat pengumpulan data menggunakan lembar observasi, rubrik penilaian, soal-soal tes kemudian dianalisis dengan data deskriptif kuantitatif. Hasil penelitian menunjukkan peningkatan persentase hasil belajar siswa pada siklus I siswa yang tuntas hanya $68 \%$ dan meningkat ke siklus II menjadi $91 \%$. Keaktifan siswa juga mengalami peningkatan. Pada siklus I siswa sangat aktif sebanyak 7 siswa (32\%), siswa aktif 8 siswa (36\%) dan siswa cukup aktif menjadi 7 siswa (32\%). Peningkatan terjadi pada siklus II dengan siswa sangat aktif sebanyak 17 siswa (77\%), siswa aktif menjadi 5 siswa (23\%). Dari hasil tersebut, dapat dinyatakan bahwa model Discovery Learning dapat meningkatkan keaktifan dan hasil belajar siswa kelas IV SD N Karangtengah 01.

Kata Kunci: Keaktifan, Hasil Belajar, IPA, Discovery Learning

Abstract

This research is motivated by the activeness and learning outcomes of students who are still low in SD Negeri Karangtengah 01 on IPA content. The purpose of the study is to increase the activeness and learning outcomes of science through the application of Discovery Learning. This type of research uses Classroom Action Research (CAR). Data collection techniques are observation, and learning outcomes tests. The research subjects were 22 fourth grade students of Karangtengah 01 Elementary School. The data collection tool used observation sheets, runric assessment, test questions then analyzed with quantitative descriptive data. The results showed an increase in the percentage of student learning outcomes in the first cycle of students who completed only $68 \%$ and increased to the second cycle to $91 \%$. The activity of students also increases. In the first cycle the students were very active as many as 7 students (32\%), active students 8 students (36\%) and quite active students to 7 students (32\%). The increase occurred in cycle II with very active students as many as 17 students (77\%), active students became 5 students (23\%). From these results, it can be stated that the Discovery Learning model can increase the activity and learning outcomes of fourth grade students at SD N Karangtengah 01.
\end{abstract}

Keywords: Activity, Learning Outcomes, Science, Discovery Learning 


\section{Pendahuluan}

Proses pembelajaran dalam Kurikulum 2013 menuntut siswa menjadi pusat pembelajaran dengan melakukan kegiatan mengamati, menanya, mengumpulkan informasi, mengasosiasi, dan mengkomunikasikan, dengan menggunakan pendekatan saintifik Hadi (2016:93). Menurut Fauziah (2013:167) pembelajaran di kurikulum 2013 menerapkan pendekatan saintifik yang meliputi proses mengamati, merumuskan masalah, mengajukan hipotesis, mengumpulkan data, menganalisis data, menarik kesimpulan dan mengkomunikasikan, yang digunakan untuk mengukur tingkat kemampuan siswa. Salah satu muatan yang diajarkan pada kurikulum 2013 di sekolah dasar adalah IPA.

IPA sering disebut dengan sains, pengetahuan yang mempelajari tentang gejala-gejala yang terjadi di alam (Samatoa, 2010:19). IPA adalah ilmu yang mempelajari peristiwa-peristiwa yang terjadi di alam yang diperoleh dari pengalaman melalui penyelidikan, penyusunan dan penyajian gagasangagasan,dengan melakukan kegiatan observasi, eksperimentasi, penyimpulan, penyusunan teori agar siswa mempunyai pengetahuan, dan konsep yang berkaitan dengan alam sekitar Rini \& Mawardi (2015:112). Pengajaran IPA dan keterampilan proses IPA untuk siswa hendaknya di modifikasi sesuai taraf perkembanagan kognitif siswa, karena stuktur kognitif kanak-kanak tidak dapat di bandingkan dengan struktur kognitif ilmuan. Oleh karena itu anak-anak perlu di beri kesempatan untuk berlatih ketrampilan proses IPA sehingga di harapkan akhirnya mereka berfikir dan memiliki sifat ilmiah. Tujuan pembelajaran IPA di SD yang termuat dalam Permendiknas No 22 Tahun 2006 yaitu: 1. Memperoleh keyakinan terhadap kebesaran Tuhan Yang Maha Esa berdasarkan keberadaan, keindahan dan keteraturan alam ciptaan-Nya 2. Mengembangkan pengetahuan dan pemahaman konsep-konsep IPA yang bermanfaat dan dapat diterapkan dalam kehidupan sehari-hari 3. Mengembangkan rasa ingin tahu, sikap positif dan kesadaran tentang adanya hubungan yang saling mempengaruhi antara IPA, lingkungan, teknologi dan masyarakat 4. Mengembangkan keterampilan proses untuk menyelidiki alam sekitar, memecahkan masalah dan membuat keputusan 5. Meningkatkan kesadaran untuk berperanserta dalam memelihara, menjaga dan melestarikan lingkungan alam 6. Meningkatkan kesadaran untuk menghargai alam dan segala keteraturannya sebagai salah satu ciptaan Tuhan 7 . Memperoleh bekal pengetahuan, konsep dan keterampilan IPA sebagai dasar untuk melanjutkan pendidikan ke SMP/MTs.

Maka dari itu pembelajaran IPA di sekolah dasar sebaiknya disesuaikan dengan tingkat perkembangan siswa yang masih dalam tahapan operasioanal konkret. Hal ini di maksudkan pembelajaran IPA di sekolah dasar sebaiknya menggunakan media-media konkret yang terdapat di lingkungan sekitar siswa. Menurut Ipda (2015:34) pada fase operasional konkret siswa lebih mudah memahami pembelajaran menggunakan objek fisik atau benda nyata tidak hanya sekedar mendengarkan materi yang disampaikan guru.

Berdasarkan observasi yang dilaksanakan di SD N Karang tengah 01 kelas 4 pada tanggal 10 juli 2018 diperoleh data hasil belajar ulangan harian mauatan IPA pada siswa belum mencapai Kriteria Ketuntasan minimal (KKM) pada muatan IPA yaitu 70. Dari 22 siswa hanya hanya $49 \%$ siswa yang mencapai nilai $\geq \mathrm{KKM}$. Berdasarkan observasi keaktifan belajar belajar siswa juga masuk dalam kategori rendah, ditunjukan dari 22 siswa terdapat 12 siswa (55\%) diantaranya memiliki kategori tidak aktif, 4 siswa (18\%) memiliki kategori cukup aktif dan hanya 6 siswa (27\%) yang memiliki kategori aktif. Hal ini di karenakan pembelajaran yang dilaksanakan masih menggunakan metode ceramah Saat proses belajar siswa cenderung merasa bosan, seperti siswa beramain dengan teman sebangkunya dan teman yang lain merasa terganggu sehingga siswa kurang memahami pembelajaran yang disampaikan. Pembelajaran yang dilaksanakan juga masih berpusat pada 
guru sehingga keaktifan belajar siswa juga rendah dan memepengaruhi hasil belajar.

Keterampilan seorang guru dibutuhkan untuk mengemas pembelajaran IPA supaya inovatif dan menyenangkan. Suprijono (2014:206) mengatakan "model pembelajaran berfungsi sebagai pedoman bagi para perancang pembelajaran dan para guru dalam merencanakan aktivitas belajar mengajar". Penggunaan model yang yang inovatif diharapkan dapat meningkatkan keaktifan belajar siswa. Keaktifan belajar merupakan usaha yang dilakukakan guru saat proses belajar mengajar di kelas dengan tujuan siswa mampu melakukan kegiatan secara bebas baik jasmani maupun rohani tidak takut mengutarakan pedapat, dapat memecahkan masalah, dan siswa termotivasi untuk mengikuti pembelajaran, (Muah, 2016:43). Sedangkan menurut Rohana \& Nugraheni (2014:14) keaktifan belajar adalah proses belajar mengajar yang menuntut siswa terlibat aktif dan berpartisipasi dalam pembelajaran sehingga berdampak ada perubahan tingkah laku siswa. Adapun indikator keaktifan belajar siswa menurut Sudjana (2010:61) adalah sebagai berikut: 1) pdalam melaksanakan tugasnya, 2) terlibat dalam pemecahan masalah, 3) Bertanya kepada guru atau siswa laian apabila tidak memahami persoalan yang dihadapinya, 4) berusaha mencari informasi yang diperoleh untuk memcahkan masalah, 5) melaksanakan diskusi kelompok, 6) memiliki kemamampuan diri dan hasil yang diperolehnya, 7) melatih diri memecahkan soal atau masalah 8) memliki kesempatan menggunakan atau menerapkan apa yang diperolehnya dalam menyelesaiakn tugas atau permasalahan yang sedang dihadapi. Bukan hanya keaktifan akan tetapi hasil belajar siswa akan meningkat.

Halimah dan Sumardjono (2017:270) hasil belajar merupakan kegiatan belajar mengajar yang dilakukakan guru dan peserta didik sehingga peserta didik mendapatkan pengalaman baru dari kegiatan tersebut, hasil belajar meliputi tiga aspek yaitu kognitif, afektif dan psikomotor. Widianto dan Harjono (2017:201) menyatakan bahwa hasil belajar merupakan suatu kegiatan penilaian di dalam pembelajran yang bertujuan untuk membuktikan kemampuan siswa dalam mencapai tujuan pembelajaran yang meliputi aspek kognitif, afektif, dan psikomotorik. hasil belajar adalah perubahan sikap seseorang setelah mengikuti proses belajar, dengan indikator domain kognitif anatara lain: pengetahuan, pemahaman, penerapan.

Maka dari itu penulis memiliki solusi yang tepat untuk memecahkan masalah tentang rendahnya keaktifan dan hasil belajar dengan menerapkan model pembelajaran Discovery Learning. Illahi, (2012:33) model discovery learning adalah suatu model pembelajaran yang memungkinkan siswa terlibat secara langsung terhadap proses kegiatan pembelajaran, dengan begitu sswa mampu berpikir dalam menemukan suatu konsep atau teori yang di pelajari. Model discovery learning adalah serangkaian proses kegiatan pembelajaran dengan melibatkan kemampuaan berfikir siswa dalam mencari dan menyelidiki secara sistematis,logis dan kritis. Dengan begitu siswa akan menemukan pengetahuannya, sikap, ketrampilanya sendiri dan terjadinya perubahan tingkah laku Hanafiah (2009:77). Model ini diharapkan akan melatih siswa dalam berfikir secara ilmiah dan membangun penegetahuan sendiri melalui proses pemecahan masalah sehingga siswa akan memiliki pemahaman yang mendalam tentang suatu konsep yang akan di pelajari dan berdampak pada peningkatan hasil belajar. Selain itu model pembelajaran ini menumbuhkan rasa ingin tahu siswa sehingga keaktifan akan meningkat. Karena siswa akan di latih menemukan konsep melalui langkahlangkah pembelajaran Discovery Learning.

Langkah-langkah (sintak) model pembelajaran Discovery Learning menurut Nursyahidah (2015:2) adalah: 1) Stimulation (pemberian rangsangan) Pertama-tama pada tahap ini pelajar dihadapkan pada sesuatu yang menimbulkan kebingungannya, kemudian dilanjutkan untuk tidak memberi generalisasi, agar timbul keinginan untuk menyelidiki sendiri. 2) Problem statement (pernyataan / identifikasi masalah) setelah dilakukan stimulasi langkah selanjutya adalah guru memberi kesempatan kepada siswa untuk 
mengidentifikasi sebanyak mungkin agenda-agenda masalah yang relevan dengan bahan pelajaran, kemudian salah satunya dipilih dan dirumuskan dalam bentuk hipotesis (jawaban sementara atas pertanyaan masalah). 3) Data collection (pengumpulan data) ketika eksplorasi berlangsung guru juga memberi kesempatan kepada para siswa untuk mengumpulkan informasi sebanyak banyaknya yang relevan untuk membuktikan benar atau tidaknya hipotesis. 4) Data processing (pengolahan data) Pengolahan data merupakan kegiatan mengolah data dan informasi yang telah diperoleh para siswa baik melalui wawancara, obseervasi dan sebagainya lalu ditafsirkan. 4) Verification (pembuktian) Pada tahap ini siswa melakukan pemeriksaan secara cermat untuk membuktikan benar atau tidaknya hipotesis yang ditetapkan tadi dengan temuan alternatif, dihubungkan denganm hasil data processing. 5) Generalization (menarik kesimpulan/generalisasi) tahap generalisasi menarik kesimpulan adalah proses menarik sebuah kesimpulan yang dapat dijadikan prinsip umum dan berlaku untuk semua kejadian atau masalah yang sama, dengan memperhatikan haslil verifikasi.

\section{Metode Penelitian}

Jenis penelitian ini merupakan Penelitian Tindakan Kelas (PTK). Subyek penelitian ini adalah siswa kelas IV SD Negeri Karangtengah 01, dengan jumlah siswa 22. Variabel penelitian yang digunakan adalah model Discovery Learning sebagai variabel bebas dan keaktifan siswa, hasil belajar sebagai variabel terikat. Rancangan penelitian yang digunakan dalam penelitian ini adalah model spiral yang dikemukakan oleh Kemmis \& MC Taggart dimana setiap siklus terdiri dari 4 tahap yaitu perencanaan, pelaksanaan, observasi, serta refleksi (Arikunto 2010:10). Teknik pengumpulan data dalam penelitian meliputi tes, observasi dan studi dokumen. Tes berupa tes objektif yang diberikan diakhir siklus. Sedangkan observasi pada penelitian ini dilakukan untuk mengamati tindakan guru dalam menerapkan model pembelajaran Discovery Learning dan respon siswa dalam menerima pembelajaran. Serta rubrik penilaian digunakan untuk mengukur keaktifan siswa dalam proses pembelajaran. Penelitian dikatakan berhasil meningkatkan hasil belajar siswa pada muatan IPA jika dari keseluruhan siswa dalam kelas $\geq 80 \%$ mencapai bahkan melebihi KKM (70).

\section{Hasil Penelitian}

Pada bagian ini, akan dipaparkan hasil analisis dan data penelitian tentang hasil belajar Matematika pada siswa kelas IV di SD N Karangtengah 01 dengan model Discovery Learning. Hasil belajar IPA dari pra siklus, siklus I, dan siklus II dapat dilihat pada tabel 1 di bawah ini:

Tabel 1 Perbandingan Ketuntasan Hasil Belajar Kondisi Awal, Siklus I dan Siklus II

\begin{tabular}{|c|c|c|c|c|c|c|c|}
\hline \multirow[t]{2}{*}{$\begin{array}{c}\text { Ketuntasan } \\
\text { Belajar }\end{array}$} & \multirow[t]{2}{*}{ KKM } & \multicolumn{2}{|c|}{$\begin{array}{l}\text { Kond. } \\
\text { Awal }\end{array}$} & \multicolumn{2}{|c|}{ Siklus I } & \multicolumn{2}{|c|}{ Siklus II } \\
\hline & & $\mathrm{F}$ & $\%$ & $\mathrm{~F}$ & $\%$ & $\mathrm{~F}$ & $\%$ \\
\hline Tuntas & $\geq 70$ & 9 & $41 \%$ & 15 & $68 \%$ & 20 & $91 \%$ \\
\hline Tidak Tuntas & $<70$ & 13 & $59 \%$ & 7 & $32 \%$ & 2 & $9 \%$ \\
\hline \multicolumn{2}{|l|}{ Total } & 22 & $100 \%$ & 22 & $100 \%$ & 22 & $100 \%$ \\
\hline \multicolumn{2}{|c|}{ Rata-Rata } & \multicolumn{2}{|c|}{63,63} & \multicolumn{2}{|c|}{71,80} & \multicolumn{2}{|c|}{80,73} \\
\hline \multicolumn{2}{|c|}{ Nilai Tertinggi } & \multicolumn{2}{|c|}{80} & \multicolumn{2}{|c|}{90} & \multicolumn{2}{|c|}{100} \\
\hline \multicolumn{2}{|c|}{ Nilai Terendah } & \multicolumn{2}{|c|}{40} & \multicolumn{2}{|c|}{55} & \multicolumn{2}{|c|}{60} \\
\hline
\end{tabular}

Berdasarkan tabel 1 tentang perbandingan hasil belajar siswa, diketahui bahwa terjadi peningkatan dari kondisi awal, siklus I, dan siklus II. Dari hasil pelaksanaan tindakan siklus I diketahui bahwa secara klasikal nilai rata-rata siswa sudah tercapai namun ketuntasan belajar siswa belum mampu mencapai indikator keberhasilan tindakan penelitian yang telah ditentukan sehingga masih diperlukan perbaikan pada siklus II. Kemudian tindakan dilanjutkan dengan pelaksanaan tindakan siklus II agar ketuntasan hasil belajar muatan IPA siswa bisa mencapai indikator keberhasilan yang diharapkan yaitu sejumlah $80 \%$ atau siswa mencapai ketuntasan. Sedangkan peningkatan keaktifan siswa dapat dilihat pada tabel 2 di bawah ini:

Tabel 2 Perbandingan keaktifan siswa pada pra siklus, siklus I dan siklus II

\begin{tabular}{lcccccc}
\hline \multirow{2}{*}{ Kriteria } & \multicolumn{2}{c}{ Pra Siklus } & \multicolumn{2}{c}{ Siklus I } & \multicolumn{2}{c}{ Siklus II } \\
\cline { 2 - 8 } & Jml & $\%$ & Jml & $\%$ & Jml & $\%$ \\
\hline Sangat Aktif & - & $0 \%$ & 7 & $32 \%$ & 17 & $23 \%$ \\
\hline Aktif & 6 & $26 \%$ & 8 & $36 \%$ & 5 & $77 \%$ \\
\hline Cukup Aktif & 4 & $18 \%$ & 7 & $32 \%$ & - & - \\
\hline Kurang Aktif & 12 & $55 \%$ & - & - & - & - \\
\hline Total & 22 & $100 \%$ & 22 & $100 \%$ & 22 & $100 \%$ \\
\hline
\end{tabular}


Berdasarkan tabel di atas dapat dilihat bahwa telah terjadi peningkatan kkeaktifan belajar siswa secara bertahap. Pada kegiatan pra siklus menunjukan bahwa siswa yang memiliki kategori aktif hanya 6 siswa $(26 \%)$, siswa dengan kategori cukup aktif sebanyak 4 siswa (18\%) dan 12 siswa memiliki kategori tidak aktif (55\%). Setelah dilakukan tindakan dengan menggunakan model pemblajaran Discovery Learning keaktifan siswa meningkat menjadi siswa dengan kategori sangat aktif sebanyak 7 siswa $(32 \%)$, siswa yang memiliki kategori aktif menjadi 8 siswa (36\%) dan siswa yang memiliki kategori cukup aktif menjadi 7 siswa (32\%). Peningkatan terjadi paa siklus II dengan siswa dengan kategori sangat aktif sebanyak 17 siswa (77\%), siswa yang memiliki kategori aktif menjadi 5 siswa (23\%), Dengan demikian pembelajaran dengan menggunakan model pembelajaran Discovery Learning dapat meningkatkan keaktifan siswa kelas IV di SDN Karangtengah 01. Peningkatan aktivitas guru dan siswa dapat dilihat pada tabel 3 di bawah ini:

Tabel 3 Peningkatan aktivitas Guru dan siswa

\begin{tabular}{ccc}
\hline Tindakan & Siklus I & Siklus II \\
\hline Aktivitas Guru & $83 \%$ & $100 \%$ \\
\hline Aktivitas Siswa & $72 \%$ & $100 \%$ \\
\hline
\end{tabular}

Berdasarkan tabel 3 dapat diketahui terjadi peningkatan aktivitas guru dan siswa dari siklus I dan siklus II dengan penerapan model Discovery Learning. Setelah pelaksanaan tindakan siklus I aktivitas guru mencapai $83 \%$, dan pada siklus II perolehan sktivitas guru mengalami peningkatan $100 \%$. Seirig peningkatan aktivitas guru, perolehan presentase aktivitas siswa mengalami peningkatan, pada siklus I 82\% kemudian pada siklus II perolehan skor menjadi meningkat $100 \%$.

Berdasarkan hasil observasi yang telah dilakukan oleh peneliti di kelas IV SD $\mathrm{N}$ karangtengah 01, diketahui bahwa sebelum tindakan penelitian dilaksanakan pembelajaran yang diterapkan oleh guru masih menggunakan metode ceramah, guru menilai pembelajaran menggunakan metode ceramah lebih praktis dari pada menggunakan model pembelajaran inovatif yang memerlukan banyak persiapan lebih di dalam pelaksanaannya. pembelajaran yang diterapkan oleh guru kelas IV SD N Karangtengah 01 yang menyebabkan siswa kelas IV pasif di dalam proses pembelajaran, tidak ada aktivitas belajar yang bermakna bagi siswa untuk membangun sebuah konsep materi, kegiatan dalam pembelajaran masih didominasi oleh guru sehingga dalam pelaksanaan pembelajaran terkesan monoton dan tidak menyenangkan.

Berdasarkan kondisi yang demikian maka perlu adanya tindakan perbaikan pembelajaran untuk meningkatkan hasil belajar dan keaktifan belajar siswa kelas IV SD N Karangtengah 01 dengan menerapkan model pembelajaran inovatif yaitu model discovery learning. Penerapan pebelajaran Discovery Learnig telah terbukti dapat menigkatkan keaktifan dan hasil belajar siswa pada siklus I. Pada pelaksanaan tindakan siklus I keaktifan dan hasil belajar IPA siswa meningkat. Peningkatan ini terjadi karena siswa akan dibantu menemukan sebuah konsep pembelajaran IPA dengan langkah-langkah model Discovery Learnig sehingga hasil belajar meningkat. Peningkatan juga terjadi pada keaktifan belajar siswa. Hal ini terbukti dengan siswa ikut serta dalam penyelidikan, sehingga siswa dapat mengkonstruksi pengetahuannya sendiri. Akan tetapi peningkatan yang terjadi pada siklus I belum memenuhi target indikator kinerja yang telah ditetapkan yaitu $80 \%$ dari 22 siswa, maka dilanjutkan pada siklus II. Pada siklus I dari 23 aspek observasi aktivitas guru, 3 aspek belum tersampaikan, sedangkan dari 17 aspek lembar observasi siswa, 3 aspek belum tersampaiakan, guru kurang mengkondisikan siswa sehingga berdampak pada sebagian siswa yang berbicara dengan teman sebangku dan mengganggu teman yang lain.

Perbaikan yang telah dilaksanakan pada siklus I sesuai dengan rencana berdasarkan refleksi yang dikalakukan didapatkan hasil yang lebih baik. Pada siklus II hasil belajar dan keaktifan siswa meningkat dibandingkan dengan siklus I. Peningkatan ini terjadi karena siswa mulai lebih memahami konsep pembelajaran IPA melalui langkah-langkah pembelajaran Discovery Learning dan keaktifan siswa dapat meningkat karena kegiatan pembelajaran 
yang dilakukan menuntut siswa mengkonstruksi pengetahuannya sendiri. Berdasarkan pengamatan selama pelaksanaan tindakan pembelajaran pada siklus I dan siklus II terlihat rata-rata hasil belajar IPA semakin baik dan mengalami peningkatan pada setiap siklusnya. Siswa lebih antusias dan aktif mengikuti setiap proses pembelajaran, lebih berani di dalam menyampaikan gagasan dan melakukan kegiatan tanya jawab bersama guru, dengan penerapan model Discovery Learning. Pembelajaran yang berlangsung menjadi lebih menarik dan bermakna bagi siswa, proses pembelajaran tidak hanya terpusat pada guru melainkan siswa juga ikut terlibat dalam proses pembelajarannya.

Berdasarkan uraian penelitian, maka penerapan Discovery Learning dapat meningkatkan hasil belajar dan keaktifan siswa pada siswa kelas IV Semester I SD N Karangtengah 01. Hal ini disebabkan karena siswa belajar tentang menemukan konsep melalui langkah-langkah pembelajaran Discovery Learning. Model Discovery Learning pembelajaran yang berfokus pada percobaan, penelitian sehingga nantinya sebuah konsep dapat ditemukan.Berdasarkan uraian penelitian, maka penerapan model Discovery Learning dapat meningkatkan hasil belajar dan keaktifan siswa pada siswa kelas IV Semester I SD N Karangtengah 01 Tahun Pelajaran 2016/2017 ini selaras dengan hasil penelitian yang telah dilakukan sebelumnya, dari Kristin (2016). Hasil penelitian menunjukan bahwa model Discovery Learning mampu meningkatkan hasil belajar siswa mulai dari yang terendah $9 \%$ sampai yang tertinggi $27 \%$ dengan ratarata $17,8 \%$. Penelitian dari Prayitno, dkk (2017) Pembelajaran Discovery Learning dapat meningkatkan keaktifan siswa. Pada siklus I rata-rata keaktifan siswa adalah $58,92 \%$ memiliki kategori cukup. Dan meningkat ke siklus II menjadi $85,93 \%$ dengan kategori sangat baik. Hal ini dikarenakan pembelajaran dengan model discovery learning menjadikan siswa berpartisipasi aktif dalam kegiatan diskusi dalam proses penemuan yang mereka lakukan sehingga pembelajaran berpusat pada siswa. Dari hasil penelitian tersebut terbukti bahwa penerapan model Discovery
Learning dapat meningkatkan Hasil belajar IPA dan keaktifan belajar siswa

\section{Kesimpulan}

Penelitian Tindakan Kelas (PTK) ini dilakukan di SD Karangtengah 01 dengan menggunakan model pembelajaran Discovery Learning hasil belajardan keaktifan belajar siswa kelas IV semester 2 tahun ajaran 2018/2019. Sebelum dilaksanakan penelitian sebagian siswa memiliki nilai kurang dari KKM dan keaktifan siswa masih rendah. Hal ini dibuktikan dari hasil observasi yang menunjukan bahwa hasil belajar dari 22 siswa hanya 9 siswa tuntas $(41 \%)$ dan sisaya 13 siswa beluum tuntas (59\%). Keaktifan siswa menunjukkan dalam kategori rendah, dari 22 siswa hanya 6 (27\%) siswa aktif, $4(18 \%)$ siswa cukup aktif dan sisanya 12 siswa (55\%) tidak aktif. Setelah dilaksanakan tindakan menggunakan model pembelajaran Discovery Learning pada siklus I membuktikan bahwa hasil belajar dan keaktifan belajar siswa mengalami peningkatan. Hasil belajar dari 22 siswa 15 siswa (68\%) tuntas dan hanya 7 siswa (32\%) belum tuntas. Keaktifan belajar siswa menunjukan bahwa dari 22 siswa 7 siswa (32\%) sangat aktif, 8 siswa (36\%) aktif dan hanya 7 siswa (32\%) cukup aktif. Pada siklus II hasil belajar dan keaktifan belajar siswa mengalami peningkatan. Hasil belajar siswa menunjukan dari 22 siswa 20 diatantaramya (91\%) tuntas dan hanya 2 siswa (9\%) belum tuntas. Keaktifan belajar siswa menunjukan bahwa dari 22 siswa 17 (77\%) siswa sangat aktif, dan 5 (23\%) siswa aktif. Berdasarkan hasil tersebut, dapat dinyatakan bahwa model Discovery Learning dapat meningkatkan keaktifan dan hasil belajar siswa kelas IV SD N Karangtengah 01.

\section{Daftar Pustaka}

Arikunto, Suharsimi. 2010. Prosedur Penelitian Suatu Pendekatan Praktik. Jakarta : Rineka Cipta

Fauziah, R., \& dkk. (2013). Pembelajaran Saintifik Elektronika Dasar Berorientasi Pembelajaran. INVOTEC: Innovation of Vocational Technology Education. 9 (2), 167. 
Halimah, N., \& Sumardjono. (2017). Perbedaan Pengaruh Model Student Teams Achievement Division (STAD) dan Numbered Heads Together (NHT) Terhadap Hasil Belajar Matematika Siswa Kelas V SD. SCHOLARIA. 7 (3), 270.

Hadi, W. (2016). Meningkatkan Kemampuan Penalaran Sisw SMP Melalui Pembelajaran Discovery Learning dengan Pendekatan Saintifik. Kalamtika. 1(1), 93.

Hanafiah, \& dkk. (2009). Konsep Strategi Pembelajaran. Bandung: PT Refika Aditama.

Ibda, F. (2015). Perkembangan Kognitif: Teori Jean Piaget. Intelektualita. 3 (1), 34.

Illahi, M. T. (2012). Pembelajaran Discovery Strategy \& Mental Vocational Skill. . Yogyakarta: DIVA Press.

Kristin, F., \& Rahayu, D. (2016). Pengauh Penerapan Model Pebelajaran Discovery Learning terhadap Hasil Belajar IPS pada Siswa Kelas 4 SD. Scholaria, 6 (1), 87.

Muah, T. (2016). Penggunaan Model Pembelajaran Problem Based Instruction (PBI) untuk Meningkatkan Keaktifan dan Hasil Belajar Matematika Kelas 9B Semester Gasal Tahun Pelajaran 2014/2015 SMP N 2 TuntangSemarang. Scholaria. 6 (1), 43.

Nursyahidah, F. (2015). Pembelajaran Discovery Learning Menggunakan Tangram GeoGebra untuk Menemukan Luas Persegi. AKSIOMA: Jurnal Matematika dan Pendidikan Matematika. 6 (1), 28.

Permendiknas. (2006). Permendiknas No 22 Tahun 2006 tentang Standar isi. Jakarta: Kemendikbud

Prayitno , B., \& dkk. (2017). Meningkatkan

Keaktifan Siswa Dengan Model

Discovery Learning Pada Konsep

Klasifikasi Makluk Hidup. Jurnal

Pendidikan Heyati. 3 (4), 136.

Rini, \& Mawardi. (2015). Peningkatan Keterampilan Proses Saintifik dan Hasil Belajar Siswa Kelas 4 SDN Slungkep Tema Peduli Terhadap Makhluk Hidup Menggunakan Model Problem Based Learning.
SCHOLARIA: Jurnal Pendidikan dan Kebudayaan. 5 (1), 112.

Rohana, I., \& Nugraheni, P. (2014). Penerapan Model Pembelajaran Koopratif Tipe Couse Review Horay dalam Meningkatkan Keaktifan Belajar Siswa. Ekuivalen. 7 (1), 14.

Samatoa, Usman. (2010). Pembelajaran IPA di Sekolah Dasar. Jakarta: PT. Indeks

Sudjana, N. (2010). Dasar-Dasar Proses Belajar. Bandung: Sinar Baru.

Suprijono, A. (2014). Cooperative Learning. Yogyakarta: Pustaka Pelajar.

Widiantono, N., \& Harjono, N. (2017). Penerapan Model Pembelajaran Interaktf untuk Meningkatkan Aktifitas dan Hasil Belajar IPA Siswa Kelas 5 SD. Scholaria. 7 (3), 201. 